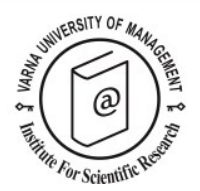

\title{
The way to Santiago beyond Santiago. Fisterra and the pilgrimage's post-secular meaning
}

\author{
Thomas Blom ${ }^{1}$, Mats Nilsson ${ }^{2}$ and Xosé Santos ${ }^{3 *}$
}

Received: 19/05/2015 Accepted: 17/10/2015

\footnotetext{
${ }^{1}$ Department of Geography, Media and Communication, Karlstad University, SE-651 88 Karlstad, Sweden; email: Thomas.Blom@kau.se

${ }^{2}$ Department of Geography, Media and Communication, Karlstad University, SE-651 88 Karlstad, Sweden; email: Mats.Nilsson@kau.se

3 Senior Lecturer on Human Geography, University of Santiago de Compostela, E-15782 Santiago de Compostela, Spain; phone: +34 630871016, e-mail: xosemanuel.santos@usc.es

* Corresponding author
}

\section{Abstract}

There is a growing demand for pilgrimage, which in turn seems to be linked to the change in content and performance that the practice of pilgrimage is undergoing. This paper examines the emergence of Fisterra as a "new" end destination for the pilgrims. The aim of this study is to shed light on and create understanding of the destination Fisterra and the meaning of the place and the role it plays for the pilgrims. Empirically, the study is partly based on statistics and official documents and partly on interviews with pilgrims at Fisterra. The study concludes that contemporary Fisterra as the end of the journey should be perceived as an effect of the post-secular trend in Europe as well as a response to the fact that the historical goal of Santiago de Compostela is increasingly marked by commercialised mass tourism, which is a disadvantage in the context of pilgrimage.

(C) 2016 Varna University of Management. All rights reserved

Keywords: pilgrim, Santiago de Compostela, Fisterra, tourism, post-secular, experientially based approach

Citation: Blom, T., M. Nilsson and X. Santos (2016) The way to Santiago beyond Santiago. Fisterra and the pilgrimage's post-secular meaning. European Journal of Tourism Research 12, pp. 133-146

\section{Introduction}

This study launches into the increasingly prominent role the place of Fisterra has gained for present-day pilgrims in Galicia. In a historically religious place such as Galicia, we can now witness how the destination is transformed and/or supplemented with pilgrims who have "abandoned" the historical religious orientation in favour of an individual-oriented spirituality (Mikaelsson, 2012, Blom et al., 2008). It is suggested that this tendency can be explored in terms of place and performance (pilgrimage) besides the partly changed content. Even the present spiritual orientated pilgrimage to Santiago de Compostela is coloured by and rests on the historical Christian content in praxis. Therefore, it is important to shed light on the reasons that make some 
pilgrims opt for Fisterra as the final destination instead of Santiago de Compostela. In this context, we take the post-secular tendencies in Western society as our starting-point for reflecting on a possibly increased inclination to choose a different pilgrimage destination.

Studies suggest that it is clear that the spiritual content of pilgrimage should be seen as a concrete mirror reflection of the contemporary post-secular tendencies in society (Eade, 2011; Lois and Santos, 2015). The post-secular preferences contribute to the development of new and alternative approaches related to pilgrimage. As a consequence of this shift, it is also argued that the post-secular tendency contributes to an altered view of the purpose and content of the pilgrimage in relation to the historical and traditional religious meaning. It is a process which involves the ongoing (re)construction of substance and practice (Collins-Kreiner, 2010; Mikaelsson, 2012).

Mikaelsson (2012) argues that Santiago de Compostela is probably the best example of the post-secular tendency towards a spiritual destination. As a result of the transformation, the substance of the pilgrimages to Santiago de Compostela has notable features pointing to the spirituality that is a keystone of the postsecular age (Pace and Giordan, 2012). In a tourism context, the post-secular has paradoxically meant that the pilgrim numbers to Santiago de Compostela have increased considerably (Santos and Lois, 2015). The paradox is that since membership in community religious groups in Europe is decreasing and the holiness of the city is originally a construction of the Catholic Church, this should logically result in a pilgrimage decrease rather than increase. In addition to the partially changed purpose and content of the pilgrimage in Galicia, the effect of the change is also manifest in the pilgrims' choice of the end-destination of the journey. Today this shift has become apparent through the fact that more and more pilgrims are choosing Fisterra, located 100 kilometres to the west of Santiago de Compostela, as their final destination. This development is fairly recent even if research has shown that, although the content is being transformed in terms of the tradition, the destination has remained indisputable (Frey, 1998; Coleman and Eade, 2004).

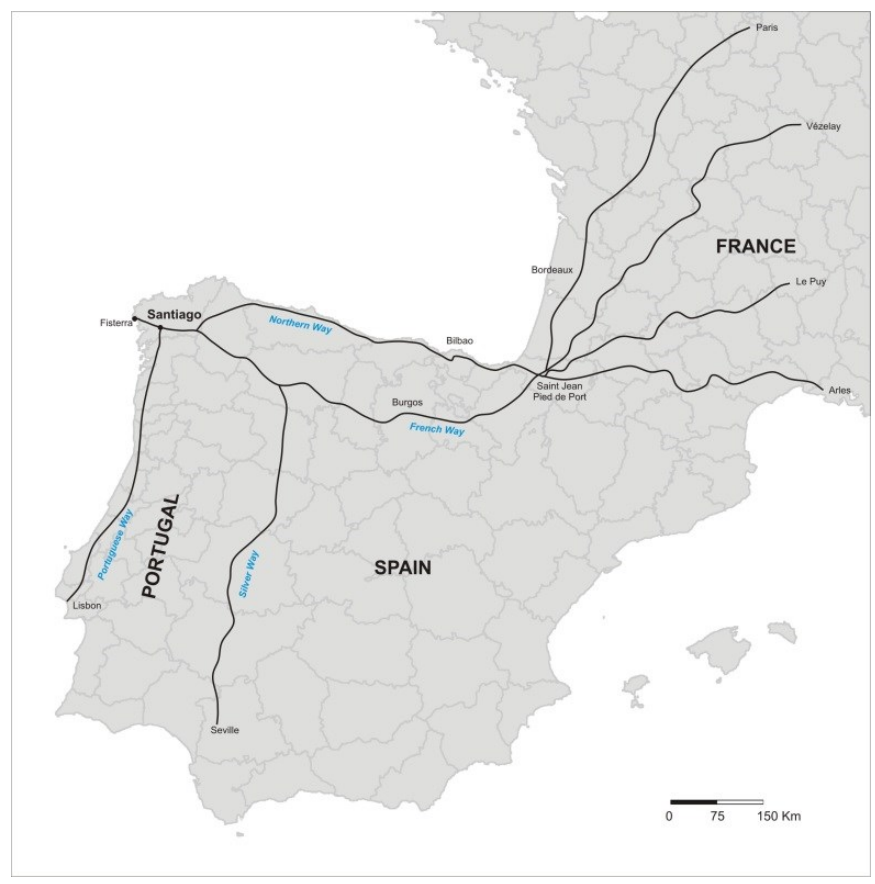

Figure 1. The Ways to Santiago 
This article seeks to introduce new nuances into the pilgrimage field. It aims to shed light on and create understanding about the Fisterra destination, and the role and meaning that the pilgrims ascribe to the journey destination. Modern literature on the pilgrimage has already demonstrated this phenomenon's profound transformation (MacCannell, 1976; Coleman and Eade, 2004; Collins-Kreiner, 2010) and authors such as Lois and Santos (2015) have analyzed the Way's post-secular character. However, there is a void when it comes to analyzing why pilgrims take to the Jacobean route, which is linked to Christian tradition, and decide to follow the path of a pagan (i.e. no religious) Way. This question opens new challenges for research by incorporating, in a lineal manner, two different meanings on the same route, which makes the distinction between the tourist and pilgrim even more difficult to define.

\section{Literature Review}

The post-secular condition

As indicated, this article contributes to the debate on the emerging post-secular society. The debate is considered to have started in the 1990s by above all Habermas (2006) and Taylor (2007). The debate was sparked by challenges to the assumption of the prevalence of secular society. It was even proposed that the notion of a secular society was "false" (Berger 1999). The decline and "disappearance" of religion in the secular society was questioned (Berger, 1999; Habermas, 2006; Gökariksel 2009; Torpey 2010). The difference between a secular society and a post-secular society is that the former term involves a distinction between the religious and the political at society level while the latter rejects this distinction and is rather a term reflecting the existence of religion in both the political and the social spheres. For the post-secular proponent Habermas (2006, 2008), the post-secular turn is rather to tell the "truth" that the religious dimension has never disappeared as an influential factor. Rather, it has been there but now it is re-organized (Gökariksel 2009). The debate has instead focussed on, and observed how the transformation of society has led to a so-called post-secular society, parallel to secular society (Sigurdson, 2009; Beaumont and Cloke, 2012).
The contemporary new phenomenon, if it really is new, is that religiosity has reclaimed a position in society as a force to be reckoned with and has thus inspired new understandings and discussions (Davie, 2000; Habermas, 2008; Beaumont and Baker, 2011; Moberg and Granholm, 2012). Taylor, one who has discussed the post-secular meaning, emphasises that we are on the threshold to an age in which" the hegemony of the mainstream master narrative of secularization will be more and more challenged" (Taylor 2007, 534). Davie (2000) also stresses that there is a contemporary religious turning point making an impact on Western Europe. In the analysis of social phenomena, the discussion has primarily involved issues of political philosophy and social theory critique. However, studies show that individual personal belief and practice indicate a private pluralism in the religious dimension (Davie, 2000). We can note that religion has regained its position in the public as well as the private sphere. There is therefore every reason to pay attention to the prominence of religion (Habermas, 2006; Sigurdson, 2009). The growing awareness of the emergence and establishment of new alternative religious movements is, for example, a noticeable development. One approach to take to the post-secular condition is that what is new is not new per se but is a return to the traditional way of viewing religion. In some studies this is called "the return of religion" or, as D. Bell (1977) put it, "the return of the sacred", a concept about which he has no doubts.

Still, the post-secular condition is not to be seen as a retrograde step but as a return with a difference in content. The current form of religiosity does not simply focus on traditional belief and practice but rather on features of individual expressions in beliefs and creeds, under the name spirituality. In the post-secular perspective, religion is more commonly seen as a "partner" in the understanding of the early "dogma"-inspired decrees. In the spirit of Habermas (2006), the post-secular implementation of religion in practice can express a general direction on existential issues, human communities and solidarities. Post-secular religiosity should thus be seen as a marketer of social contexts as it is 
transferable to the expectations and aspirations of civil society.

\section{Place in relation to post-secular development}

In recent years, the post-secular has been a buzzword in contexts where a change has been noted in the relation between the religious sphere, on one hand, and the political sphere and the state, on the other. The societal development described also reflects the state of affairs in tourism with its expanding religious and pilgrimage branches (Digance, 2003; Devereux and Carnegie, 2006; Collins-Kreiner, 2010; della Dorra, 2012; Mikaelsson, 2012). The arguments developed in the present article involve the post-secular and place in relation to the individual perspective. Theoretically, we draw on studies of the post-secular religious movements in Europe in relation to tourism, in particular the pilgrimage route between Santiago de Compostela and Fisterra. Our concern is not concrete facts about religion per se but how place is interpreted and understood against the backdrop of post-secular development in society and in the light of pilgrimage as a tourism-related experience. Lois and Santos (2015) have, for instance, related the recovery of pilgrimage and cultural routes to post-secularism, thus linking space to religion or spirituality.

\section{Journey as pilgrimage}

The pilgrimage constitutes one of the most well known phenomena related to tourism and is associated with both religion and culture and has a clear relevance to place. Eliade (1969) fairly early paid attention to the phenomenon of pilgrimages in terms of a geographical perspective on localisation. In more abstract terms, pilgrimages are undertaken to a place where a previously secular place is supposed to have transformed into a sacred place on the basis of its history and its tradition. In an abstract perspective, Eliade (1969), like Tuan and Strawn (2009), chooses to ascribe a symbolic meaning to a place that the pilgrim can understand as the "centre of the world". Turner (1969) also refers to this when he emphasises that the goal of the pilgrimage often has an unambiguous symbolism and is culturally significant. He also shows that the characteristic feature of such places is that the sacred places per se can be densely populated but very often located relatively peripheral in terms of a population agglomerate. Turner (1969) contribution to the pilgrimage research is primarily his introduction of social conceptions such as that the pilgrimage should be seen as a ritual process. Cohen (1992) extends this idea when he demonstrates that the ritual process becomes more orthodox, depending on the respective religion, when the goal of the journey is one of the major pilgrimage destinations. The effect of a pilgrimage on a place is that the sacredness is confirmed as well as incorporated into a religious framework (Eck, 1981). The principal pilgrimage places of a religion thus serve an important function in the pilgrimage system as a whole (Cohen, 1992).

To understand the complexity of pilgrimages we have to abandon Eliade's (1969) comparatively narrow focus on place and instead highlight aspects hitherto unattended in the discussion. We would like to refer to Eck (1981), who underlines the relation between place and individual in the sense that the pilgrimage has a spiritual value for which the place constitutes a necessary factor, albeit not sufficient, for a full and complete experience. Barbers (1993) confirms that a pilgrimage is a journey for religious reasons, but also stresses that the journey can be perceived as twofold: an external journey to a sacred place and an internal journey for the spiritual purpose of inner understanding. The sacred and the religious reasons also have a place in Shinde's (2007) argumentation, but at the same time the pilgrimage as an individually motivated journey based on faith is emphasized. The pilgrimage can be said to be part of an individual quest for a better future, which means that most of our journeys can be related to pilgrimaging as our journeys are often related to a wish for a positive change of some sort. This is a form of contemplation as well as a form of spirituality that traditionally is associated with religiosity (Vukovic 1992). Turnball (1981) argues in a similar vein when he claims that a pilgrim identifies with a spiritual or religious heritage.

In recent years, published studies (see e.g. Bracke, 2008; Pace and Giordan, 2012) in different research fields under the theme 'postsecular turn' show that there is a growing 
pluralism in the religious sphere, which is more focused on the private belief and practice in which the manifestation of faith and its practice is clearly related to the individual concerned (see e.g. Kong, 2010). Religiosity has thus partly gained a new meaning aiming to lend understanding of and meaning to life instead of the previous emphasis on the religious narratives of different creeds and denominations.

\section{Tourism and Pilgrimage}

This discussion concerning the relation between tourism and pilgrimage is not new, although it is a complex concept as authors such as Belhassen et al. (2008) have pointed out. Already in 1976, MacCannell introduced pilgrimages in a tourism context and suggested that tourists are a modern form of pilgrims. There are thus good reasons to hold on to MacCannell's analogy between the pilgrim and the tourist as subjects pursuing the unknown and the extraordinary. MacCannell also points to the way the present-day pilgrims not only embark on the journey for religious reasons but are also in search of an authentic experience, which apparently is perceived as lacking in today's largely homogeneous society (MacCannell 1976; Augé, 1995; Wallenstein, 2004). Smith (1992) reinforces this duality by seeing it as a journey motivated by faith, religion and spiritual self-fulfilment as well as a secular journey based on personal or spiritual needs. This division highlights two extreme frames of reference involving more or less sacred or secular tourism. Also Turner and Turner (1978) comment on and clarify this situation by saying that "a tourist is half a pilgrim if a pilgrim is half a tourist". Graburn (1989) too underlines the equivalence between a pilgrim and a tourist by indicating the functional and symbolic similarity between pilgrimage and tourism. Tourism gives meaning to our lives and is understood as either a secular ritual (the annual holiday) or as the opposite of daily life, functioning as a rite of passage for an individual (Graburn, 1989), a form of sacralisation.

Many of those who choose a pilgrimage today experience the walking as an inner journey with religious connotations, but also as a physical performance where the actual walking is primary (Frey, 1998; Davidsson Bremborg, 2013). Tourism generally takes place in holidays during which we engage in some sort of contemplation and the places we visit are often observed in what we can call "sacred terms".

Irrespective of faith, every individual is the centre of a world in which the unique individual potentials constitute the basis of concrete action. Individual faith, however, differs in the sense that it can stem from within the individual or be externally influenced. Dewsbury and Cloke (2009) argue that there is a specific feeling generated by spiritual landscapes, which also becomes a source of new understanding of conviction, faith, religion and "being in the world". We can see variations in three dichotomous dimensions: sacred profane, religion - spirituality and pilgrimage tourism.

\section{Empirical Setting: Fisterra - a destination of becoming}

There is an abundance of literature in all areas discussing the characteristics and the meaning of the Way to Santiago (Murray and Graham, 1997; Frey, 1998; Santos, 2002; Lois and Somoza; 2003; Blom et al., 2008; Lois and Santos, 2015). This medieval pilgrimage route resurfaced with force at the end of the twentieth century. In this context sufficient attention has not been given to the extension of the pilgrim's way beyond the city of Santiago de Compostela. Previous research on the route of Fisterra is scant. There are, for example, very few statistical data due to the fact that existing studies are based on the figures and information provided by the Office of the Pilgrims, where only people who take the Compostela route are registered. In addition, it is a secondary, albeit unique, route that does not end in Santiago, which is a fundamental reason for the lack of scholarly attention to date. However, there are some studies that focus on this theme. A case in point is Herrero (2008 and 2009), who reflects on the tourist gaze towards the myth of Fisterra as the end of the world and links it to the current and historical area of the road of Santiago. The myth provides a sense of place, which can serve as the basis for the creation of a tourist experience in which the road itself is the main 
feature of a secularised experience (Herrero, 2009). Finally, Lindkvist and Holmgren (2014) have provided a theoretical and analytical approach to the European Land's End. Based on the theory of centre-periphery and related paradigms, they discussed tourism competitiveness in relation to remote places that are full of symbolism.

Fisterra is a place described as the edge of the world. It is one of several places in the world that has assumed the role of being the end or the beginning of something. For centuries, the place has been seen as the edge of the world (Alonso, 2002; Trillo, 2010). Pilgrims, who have primarily walked to Santiago de Compostela, have chosen, and increasingly choose, to continue their walk to the cliffs and the lighthouse at Fisterra. Usually, such journeys can be seen as a matter of personal change, with the symbolic meaning that individuals can end a part of their lives and embark on a new phase of their life journeys. The place as such is not only a geographical end- or starting-point but also a personal crossroads that may lead to a life change.

Bearing in mind that the Church does not recognize this route and treats it simply as tourist route and destination, the complexity stems from the different perspectives of the Church and the regional public administrations, both of them also with internal contradictions. From the point of view of the Church of Compostela, it is clear that the route towards Fisterra is not a pilgrimage. However, the Church does acknowledge that the journey in the opposite direction has the character of a pilgrimage. Despite the objections of the Church, the potential for tourism development of the route to Fisterra was supported by public administrations. Apart from promotional actions the route was signposted. There are few public data about the admissions of the route of Fisterra because the Office of the Pilgrims only provides information on the routes that end in Santiago. All that can be said is therefore that the percentage fluctuates between 0.1 per cent and 0.2 per cent for the route that starts in Fisterra-Muxia, with a significant growth from 202 persons in 2011 to 652 in 2014 (http://peregrinossantiago.es/eng/pilgrims-office /statistics/).
It is even more complicated to account for pilgrims walking from Santiago to Fisterra. On the one hand there is information relating to the issue of the Fisterrana certificate, which in 2014 was 22987 compared with less than 2000 in 1998. On the other, little is known about the percentage of pilgrims who do not collect the document. In the case of the Compostela, it is estimated that between 7 and 10 per cent of the pilgrims do not collect the document. For the Fisterrana route the value is probably somewhat higher because it has less historical and symbolic value. On the other hand, the overnight stays in the Fisterra hostel can be another approximate indicator, as the pilgrims are only allowed to stay there for one night. The figures have grown from 5000 in 2003 to approximately 25000 at present. In addition, not all walkers stay overnight at destination, and we also need to take into account alternative accommodation provided by at least seven private hostels and several conventional establishments, such as hotels.

In a study conducted by the University of Santiago de Compostela (http://www.usc.es $\mathrm{gl} /$ institutos/cetur) between the years 2005 and 2010 , it was found that around 30 per cent of the pilgrims interviewed in Santiago expressed a desire to continue to Fisterra. This means around $60-65000$ walkers, a number that appears to be somewhat high considering that, there are always circumstances that prevent its realization. Frey (1998) estimated that over 10 per cent of the pilgrims continued walking towards Fisterra, a percentage that without any doubt is higher now. According to Frey (1998), this is the option chosen by the majority of people who go to Fisterra. Nevertheless, it is significant that the growth of the pilgrims to Fisterra has had a more rapid progression than that of pilgrims to Santiago, at least on the basis of the Compostela and Fisterrana certificate issues.

\section{Methodology}

The study takes a phenomenological approach to understand the manifold reasons and complex motives for contemporary pilgrimage tourism to Fisterra better. Two methods were used in the collection of the empirical data for this study. The first involved compiling empirical data from statistics and official 
documents. The second and complementary method derived empirical data from qualitative interviews of 26 pilgrims, as they defined themselves, in Santiago de Compostela. The interview procedure draws on the Biographic Narrative Interpretive Method (BNIM) (Wenngraf, 2001). It is a passive interview technique, which means that it built on the principle of non-interruption, and it is based on a single, initial narrative-inducing question. The question in our study was: "I would like you to tell me the story of your pilgrimage/travel to Fisterra - thoughts, ideas, plans and practice". This initial question to the respondents set off their narratives and they finished the story without any interruption. Because the interviews took place when they reached the end of the journey, the pilgrims' narratives conveyed their immediate conception and experience of Fisterra. The interviews, which were voluntary and conducted in English, ranged from 15 minutes to an hour and were held on site with international pilgrims. The pilgrims were interviewed individually (14 participants), or in groups (6 groups of 2 persons in each group).

The methodological process in the analysis of the empirical material was that the interviews were first transcribed in entirety. In order to provide nuanced accounts of the narratives and experiences as well as to draw out the multiple ways in which Fisterra was perceived in and through the visit, the categories emerging in the analysis of each transcribed text were first established and then compared with those of all texts in order to identify common themes strongly linked to the empirical interview data. In other words, when categories from individual stories were compared and grouped, common themes could be identified in the stories. To reduce the risk of creating erroneous themes, the themes are fairly wide. The resulting thematic dimension provides a greater understanding of the pilgrimage undertaken and the role and the value of Fisterra in their journey

\section{Findings. Fisterra -choice and meaning}

The arrival at the "end" and the pilgrim/tourist divide

The arrival in the city of Santiago de Compostela signifies a momentous break in relation to the route followed for the pilgrims. It is not only a matter of reaching the expected end of the pilgrimage and actually stop walking, but it is also a transformation into being part of something new, compared to the "usual" of being a part of "the Way". The most frequent problem the respondents commented on is the high commercialisation of the city of Santiago de Compostela. They related negatively to it as a centre of tourism. It is clear that they developed a feeling of becoming a part of the Santiago de Compostela tourism product. Brian, from London, explained that he "... felt that other looked at him [as pilgrim] as the main attraction". For others, it was the change of arriving in an urban area with a high tourist pressure that helped to disperse the idea of being a pilgrim. In fact, the behaviour of the pilgrims in Santiago de Compostela in general tends to be tourist-like. It follows that the transformation into a tourist coupled with the disappointment of an urban, tourist destination leads to a wish to extend the route to Fisterra. At this point, the respondents also seemed to undergo a metamorphosis from being pilgrims to identifying with tourists with secular forms of expression. One of the respondents stressed that it is a form of metamorphosis to come to Santiago de Compostela: "I wanted to be a pilgrim with religious undertones. We ended in Santiago and for me it is the real end of the journey. Now when I am here [Fisterra] I am a tourist." This experience can be clearly illustrated by the statement of some of the respondents.

Frey (1998), in her anthropological study of the Way to Santiago, devotes some pages to Fisterra. She emphasises the disappointment felt by some pilgrims with the classic goal of Santiago and even with some stages of the path. The massification and marketing generate frustration and, in these cases, Fisterra appears as more highly valued. It represents the end, the renaissance and at the same time, allows individuals to connect with the Celtic traditions imbuing part of European culture (Frey, 1998).

It is to be noted, that the tourist character that the pilgrims seem to acquire when they reach Santiago is maintained throughout the route to Fisterra. For the majority, however, the 
The way to Santiago beyond Santiago. Fisterra and the pilgrimage's post-secular meaning.

extension to Fisterra was meant to provide the expected [religious] experience, which is why they chose to continue towards Land's End. Samuel, from USA, said that "[Santiago] was not the feeling of the first days [of the pilgrimage] and we wanted to feel that again.'

A significant number of the persons interviewed indicated that the journey to Land's End was primarily a tourist trip. However, it is not a unanimous view, and there are several interesting nuances.

\section{The decision to leave}

Our empirical study shows that the decision to include Fisterra in the Way varies among the pilgrims. For some of the pilgrims the motivation to continue to Fisterra was a decision that had been taken in advance. Sara, from Holland, explained, "Fisterra was the enddestination from the beginning". So far, for the majority of the Fisterra pilgrims Santiago de Compostela was the intended end of their journey. For them the idea of changing the end of their journey to Fisterra was developed along the way. What had aroused their curiosity and also made them change their end-destination to Fisterra was that they learnt about the place from other pilgrims during "the Way" or they knew about it in advance. However, the final decision to shift and actually walk on towards Fisterra was not taken until they began walking the last 100 kilometres or particularly after they had reached their primary goal, Santiago de Compostela. For all those who decided along the way, the primary and main reason was that they generally had time, or had time left before the scheduled departure from the area. Nevertheless, there are differences, especially in regard to why they chose to continue to Fisterra after Santiago de Compostela. Some of them simply became aware that they had time left and chose to continue. But for most of them, it was a result of a deep disappointment with the mass tourism besieging Santiago de Compostela. It is reasonable to describe some of the decisions to continue the journeys as an anti-movement to the touristification of Santiago de Compostela. Hilde, a young person, said that "...it [Santiago de Compostela] was too much tourism, yes only tourism". The visibility of tourism is something that is recalled in several narratives. This is a recurrent notion in the narratives. The incentives to continue walking can be described as both physical and mental, and usually intertwined. There seems to be a push rather than a pull factor preceding the decision to make Fisterra the end-destination.

\section{Reasons for being here [Fisterra]}

Authors such as Lois and Santos (2015) or Santos and Lois (2011) have argued that the spiritual character of the Way to Santiago is indeed linked to post-secular thinking. Our interviews also show that the post-secular characteristics are distinctive features of the route to Fisterra.

The primary reasons for undertaking the journey to Fisterra are individual spiritual longings. Individuality in connection with the respondents' pilgrimage to Fisterra is evident when a woman named Helena said: "For me a pilgrimage is what you make it". It is a common view to see the pilgrimage as something individual rather than to see it as something regulated by the church. In other words, there is a desire to reach fulfilment by searching inside themselves. As Dennis from Slovenia put it, the reason was "to get in touch with yourself and your mind". The individual perspective seems to be significant for most of the pilgrims. The pilgrims often return to seeing themselves as a medium to reach something, often related to their lived lives, or future lives. The self-reflective (finding their own selves or making an inner journey) aspect of their visit to Fisterra serves as a central part of the role of the place. In other words, for at least some of them the earlier burden of the presence of the Church attributes on the way to Santiago de Compostela is relieved on the extension road toward the end of the world, Fisterra.

There is a great deal of symbolism related to Fisterra. There is, on one hand, a historical element that should not be ignored. Several of the pilgrims speak about the tradition to reach the "end of the World", and also in a historical perspective, as one said: "...it was the end of the world, the known world". Nowadays, the awareness that the place is not "the end", as in Medieval Ages, is now obvious. Still, the symbolic meaning is retained and was seen as the original end of the pilgrimage. Some of the 
pilgrims expressed the idea that "this is the real end" or as one of them emphasised "...it is the [Christian] church that created Santiago de Compostela". Meanings are extended to the content of the pilgrimage as a feeling of freedom, including even the choice of enddestination: "You walk as long as you want to", as one of our pilgrims put it. It is evident that for some pilgrims the individual choice is important. The continuation to Fisterra is a form of act of liberation from the story of St. James the Great and the meaning strictly tied to Catholic Church. A sixty-nine-year-old, woman was particularly distinct in her view of the difference between Santiago de Compostela and Fisterra. She declared Fisterra's independence by stating: "It has nothing to do with St. James [the Catholic Church]".

The geographical spiritual symbols are highlighted in their narratives. They stress the importance in expressions of in-betweenness, manifested by aspects of the ocean in relation to the land as well as the sunrise and sunset. All these aspects are given deeper meanings, such as: "Fisterra is a departure point and any departure point is a choice". The significance of place is individualised as a changing point: to continue or to go back.

In contrast some believed that they were on a continued pilgrimage while for others there was a distinct divergence from the pilgrimage. They expressed a personal change in their own identification of being in Santiago de Compostela, their pilgrim end destination, and being in Fisterra, where they have become "normal" tourists. After Santiago de Compostela, it seems that the "life" as a pilgrim is behind them and that they step into a concept that emphasises a new way of being with secular forms of expression. Falling into the category of being a tourist is compared to living the "life" of a pilgrim. The primary objective of the extended journey to Fisterra was for them to see the place: "...here I see as a tourist what I was doing as a pilgrim". Another issue that emerged was that they needed time and space to rest after the pilgrimage. A woman called Cecilia revealed that she "came here [Fisterra] for contemplation and needed to just be still", because she felt tired both mentally and physically.
The diminishing religious meaning of Santiago de Compostela and the increasing spiritual meaning of Fisterra

There is a clear attraction in reaching Fisterra and Land's End, partly to attain the peace and quiet missing in Santiago de Compostela and partly to focus on the walk. The respondents also stress the importance of meeting other travellers.

While Santiago de Compostela builds its identity and appeal to attract pilgrims as well as tourists, there is an obvious risk that this twofold targeting will jeopardise the fascination and radiance that the city has had for so long and still has. There is a danger in the ambition to attract even more visitors to both The Camino and Santiago de Compostela as it can lead to a gradual shift in the balance between those who are pilgrims and those who are primarily tourists.

The pilgrims and those who see themselves as tourists, in many cases have a preunderstanding of Fisterra and what it can offer in terms of spiritual satisfaction. Today, the pilgrims are an important element in Santiago de Compostela as a tourist product, but should the pilgrims feel that the place has lost its soul and that the secular expressions increase and gain ground, the attraction for pilgrims might be lost. This will affect the total number of visitors since the pilgrims add to the attraction. This problem was highlighted by one of the respondents in the following way:" They seem like pilgrims escaping from Santiago. Fisterra becomes instead the answer you are looking for".

The distance between these places does not have a clear religious connection, only a spiritual one. Furthermore, it is perceived to compensate for the lack of peacefulness in Santiago de Compostela and to give the chance of contemplation that is not offered to the same extent anymore. The interaction between the tourist and the destination is crucial to understanding the satisfaction of the trip (Kirillova et al., 2014) and, in the case of the pilgrims (at least some of them), the interaction with Santiago does not seem to be ideal. 


\section{Discussion}

Santiago de Compostela is still the end point of the pilgrimage in Galicia to most of the pilgrims, which is why all the pilgrims strive to reach this destination. Together with the road and the motivation, it is the goal that makes up the third basic element of every pilgrimage (Lois and Santos, 2015). The road of Fisterra indicates the transformation of the traditional goal and, above all, the clear separation of the city of Santiago de Compostela as a tourist destination and the Road of Santiago de Compostela as a pilgrimage destination. Contemporary pilgrims express their unhappiness with the tourism expansion in Santiago de Compostela, which they think affects the city's status as a destination of a pilgrimage. It does not meet their expectations in relation to the story and the atmosphere that serve to underpin the legend, and they are disappointed. They perceive a clear divide between tourism and pilgrimage and they experience being transformed into a common tourist regarding content and practice when they arrive in Santiago de Compostela. According to the empirical interview data, the city has turned into a tourist destination. This transformation is seen as a negative factor. Fisterra therefore appears as a better alternative, as a sacred place, in comparison with Santiago de Compostela, which to them represents a space desecrated by mass tourism. The data handled by the Tourist Observatory of Santiago de Compostela as well as interviews with walkers in Fisterra reveal the misalignments between what was expected and what was found in Santiago de Compostela. It is its confusing ambiguity of appearing as a tourist destination while promising to be a pilgrimage destination that urges the pilgrims to continue their walk to Fisterra.

This hypothesis links in with ideas developed by authors such as Collins-Kreiner (2010), who relates modern pilgrimage to post-modernism. This dedifferentiation process between tourist and pilgrim, which she refers to by naming authors such as MacCannell (1973), Graburn (1989) or Frey (1998), among others, seems to be confirmed in the case of the Way to Santiago de Compostela. We note multiple and mixed tourist, religious and spiritual or secular motivations and transitions on the route. The pilgrimage's ritualistic character is reinforced in Fisterra as it is seen as a symbolic place for the end of the world and has a spiritual meaning "and the spiritual experiences which constitute for a new meaning in life" (Collins-Kreiner 2010, 452).

The Way to Santiago de Compostela and its extension to Fisterra indicate the complexity of our society as well as its post-secular character. Torpey (2010) suggests that even although the exceptionalism in Western Europe is related to post-secularism, the "religious demand is relatively consistent across time" ( $p$. 292); as a matter of fact, there is a reorganization of religion (Gökariksel, 2009). Torpey (2010) points out that religiosity, at least in Western Europe, expresses itself through spirituality instead of other more institutionalized forms: "believing without belonging" as Davie (2000) puts in her thesis. Pilgrimage in Fisterra today is seen as an individual action, far from church structures. This is not to say that there is no sense of communities or of being part of a community (Turner 1969; Frey, 1998), including all the social surroundings, the shared experience (Wang, 1999). That is why the road to Fisterra becomes a sublimation of the pilgrimage itself, even if the walkers define themselves as tourists. Notwithstanding, they seem to recognise the symbols, rituals and the meaning of place, which are all core elements of the pilgrimage (Eliade, 1969; Tuan and Strawn, 2009).

The road to Fisterra, clearly signals the differentiation between tourists and pilgrims that Collins-Kreiner (2010) points to. The same persons define themselves in a different way when arriving at Fisterra compared to arriving at Santiago de Compostela. But regardless of how they define themselves, they are contributing to the (re)sacralisation of a new place, Fisterra, in performing and incorporating all the rituals and symbols, thus creating a pilgrim landscape in the way that Alderman describes (2002). We want to go beyond Poria et al. (2003) and their suggestion that the visitor's experience and mental state can change in intensity depending on their personality. Such a change occurs when they 
arrive at Santiago de Compostela, when the weight of being a pilgrim gives way to being the tourist; even if they in some way remain a pilgrim. The central point is how they understand the experience: "...here I see as a tourist what I was doing as a pilgrim" (Karl a pilgrim from Germany).

As Poria et al. (2003) point out, the perception of the place is central for understanding the visit. In this case, the meaning and the characteristics of Fisterra are indicated as the main inputs incentives for going on beyond Santiago de Compostela. Going further than Santiago does not always imply an opposition to Compostela; it can also be a reinforcement of the individuality. For some of them, the central point is the symbolism of the edge of the world (Lindkvist and Holmgren, 2014), as related to the Jacobean tradition, but for others the main reason is the frustration with Santiago and the need they feel to dissociate the religious way as well as the city of Santiago. In both cases, the pursuit of authenticity is the main argument (MacCannell, 1976).

This apparent rupture between one goal and another should be modified because in reality the same walkers are involved. The route to Fisterra is, in fact, an extended journey for those who have reached Santiago. This allows us to affirm that we are faced with a clear example of post-modernism and postsecularism in which the motivations are combined and complement each other without contradictions. Some of these ideas have already been clearly stated by Lois and Santos (2015) and Santos and Lois (2011). It is even possible to go a bit further, noting that to some extent it is the dissatisfaction with the traditional goal, Santiago de Compostela, which leads many pilgrims to go in search of another. We can here say that it is a form of search that represents the re-sacralisation of a place with strong animist roots. Therefore we are not talking about secularisation but spirituality, which is a keystone of the post-secular, linked to old ways of interpreting the meaning of nature.

From an organisational point of view, it is obvious that the same network of public shelters is involved and the passport stamped, thus allowing the pilgrim to obtain both credentials: the Compostela and Fisterrana. However, there is a difference, apparently substantial enough to deserve clarification. The Cathedral of Santiago, which is the required religious pilgrimage goal, is replaced by a goal of a clearly profane character. At Fisterra, the Jacobean rites are transformed into sea baths, into the burning of clothes or into the contemplation of the sunset, all of which are linked with ancient traditions of fertility, rebirth and the worship of the sun (Alonso, 2002).

Fisterra as the end and the beginning assumes a crucial symbolic value, transforming this place into a "center out there" (Turner, 1969). As Cohen observed $(1979,181)$, the structuralfunctionalist theory presumes "that the spiritual centre of the modern individual will be normally located within the confines of his society". Spirituality must be interpreted as a religion. Torpey (2010), discussing spirituality, points to the relevance of the cultural perspective, which indicates that Eastern religions, are usually not seen as religions in the West but as spiritual movements.

The great strength of Fisterra lies in the fact that its end point is consistent with the pilgrims' motivations and also with the route itself. The growing leading role of Fisterra, however, comes with a whole series of difficulties. The decision to continue the pilgrimage beyond Santiago city is still largely improvised. As a result, it is a decision not always made before arriving to Santiago, but rather mostly because there is time left to spend. In addition, the strategies of the Catholic Church must be taken into account, as the influence of the Church should not be underestimated. The Church is, without doubt, the most interested stakeholder in ensuring that Santiago continues to have the leading role, the centre of the world.

However, we cannot forget that the destiny of both sites depends on a single tourist product, namely the Road of Santiago, which includes the same visitors. The pilgrims who arrive in Compostela are the same who go to Fisterra later. This last destination is, therefore, contingent on the success of the Jacobean pilgrimages, since only subtle differences in the motivation have been shown throughout this 
article. As yet, Fisterra simply remains a byproduct, an extension or a consequence, of the Jacobean phenomenon despite its increasing visibility.

\section{Conclusion}

In conclusion, this study shows that contemporary Fisterra as the end of the journey should be understood both as an effect of the post-secular trend of individual religiosity and as a response to the negative trend (in this context) of increasingly commercialised mass tourism invading the historical goal of Santiago de Compostela. As yet, Fisterra is not, however, an independent pilgrimage destination, although it is on the rise both as a pilgrimage end and as a tourist destination for the pilgrims who finished their pilgrimage in Santiago de Compostela.

Belhassen et al. (2008) introduce the idea of theoplacity as a useful conceptual tool where place, action and beliefs combine and allow a better understanding of authenticity. Fisterra appears as a place where sacralisation is in progress, bearing in mind that sacred places are a social construction through a process of authentication (Belhassen et al. 2008).

Three elements make up a pilgrimage route, (Lois and Santos, 2015): the Way, the Motivation and the Destination. Of these, destination seems to be more conflictive as the role of Santiago is challenged by Fisterra, which appears to be the new end point. The meaning and consequences of this challenge needs to be studied further as it is evident that Fisterra now works as a prolongation of the Way to Santiago despite the Church's misgivings

If the Way to Santiago so far has been an example of the modern pilgrimage movement (Murray and Graham, 1997; Frey 1998; Tilson, 2005; Blom et al, 2008; Lois and Santos 2015), it now begs the question if its evolution and transformation can be a symptom of generalised changes in other routes, which have been developed in various corners of Europe, following on the success of the Jacobean route. As Collins-Kreiner (2010) has demonstrated, pilgrimage is not a static phenomenon but is always in a state of change, contingent on the transformations of society.

This article clarifies the differences among pilgrims walking the Way to Santiago in terms of the perception of its meaning and authenticity, as well as affirms the post-secular and post-modern character of the walk by identifying the alternating transitions from religion to spirituality and from tourist to pilgrim.

\section{References}

Alderman, D. (2002) Writing on the Graceland Wall: On the importance of authorship in pilgrimage landscapes. Tourism Recreation Research 27 (2), 51-58.

Alonso, F. (2002). Historias, leyendas y creencias de Finisterre. Betanzos: Briga.

Augé, M. (1995) Non-Places: Introduction to an Anthropology of Supermodernity. Verso, London, New York.

Barber, R. (1993) Pilgrimages. London: The Boydell Press.

Beaumont, J. and Baker, C. (2011) (Eds.) Postsecular Cities. Space, Theory and Practice, London: Continuum.

Belhassen, Y., Caton, K., and Stewart, W. (2008) The Search for Authenticity in- the Pilgrim Experience. Annals of Tourism Research 35 (3), 668-689.

Bell, D. (1977) The Return of the Sacred? The Argument on the Future of Religion. The British Journal of Sociology 28 (4), 419-449.

Berger, P. (Ed.) (1999) The Desecularization of the World: Resurgent Religion and World Politics. Washington: The Ethics and Public Policy Center.

Blom, T., Nilsson, M., and Santos, X. (2008) Pilgrimage or Sacred Tourism? A Modern Phenomenon with Historical Roots, with Examples from Fátima and Santiago de Compostela. Journal of Tourism and Development 9, 63-78.

Bracke, S. (2008) Conjugating the modern/religious. Conceptualizing Female Religious Agency: Contours of a "PostSecular" Conjuncture, Theory, Culture and Society, 25(6), 51-67.

Cohen, E. (1979) A Phenomenology of Tourist Experiences. Sociology 13 (2), 179-201.

Cohen, E. (1992) Pilgrimage centers. Concentric and excentric. Annals of Tourism Research 19 (2), 33-50. 
Coleman, S., and Eade, J. (2004) Reframing Pilgrimage: Cultures in Motion. London: Routledge.

Collins-Kreiner, N. (2010) Researching Pilgrimage. Continuity and Transformations. Annals of Tourism Research 37 (2), 443456.

Davidsson Bremborg, A. (2013) Creating sacred space by walking in silence: Pilgrimage in a late modern Lutheran Context, Social Compass, 60(4), 44-560.

Davie, G. (2000) Religion in modern Europe: a memory mutates. Oxford: Oxford. University Press.

della Dorra, V. (2011) Setting and Blurring Boundaries: Pilgrims, Tourists, and Landscape in Mount Athos and Meteora. Annals of Tourism Research, 39(2), 951974.

Devereux, C. and Carnegie, E. (2006). Pilgrimage: Journeying Beyond Self. Tourism Recreation Research, 31, 47-56.

Dewsbury, J.D. and Cloke, P. (2009) Spiritual landscapes: Existence, performance and immanence. Social and Cultural Geography 19 (6), 695-711.

Digance, J. (2003) Pilgrimage at contested sites, Annals of Tourism Research, 30, 143159.

Eade, J. (2011) "From Race to Religion: Multiculturalism and Contested Urban Space." In Beaumont, J., Ch. Baker (ed.) (2011) Postsecular Cities. Space, Theory and Practice. London: Continuum, 154-167.

Eck, D. (1981) India's Tirthas: 'Crossings' in Sacred Geography. History of Religions 20 (4), 323-344.

Eliade, M. (1969) The quest: History and meaning in religion. Chicago: University of Chicago Press.

Frey, N. (1998) Pilgrim Stories. On and off the road to Santiago. Berkeley: University of California Press.

Graburn, N. (1989) Tourism: The Sacred Journey. In Smith, V. (ed.) (1989) Hosts and Guests: The Anthropology of Tourism. Philadelphia: University of Pennsylvania Press, 21-36.

Gökariksel, B. (2009) Beyond the officially sacred: religion, secularism, and the body the production of subjectivity, Social and Cultural Geography 10 (6), 657-674.
Habermas, J. (2006) Religion in the Public Sphere. European Journal of Philosophy 14, 1-25.

Habermas, J. (2008) Notes on the post-secular society, New Perspectives Quarterly, 25(4), 17-29.

Herrero, N. (2008) Reaching Land's End: new social practices in the pilgrimage to Santiago de Compostela. International Journal of Iberian Studies 21 (2), 131-149.

Herrero, N. (2009) La atracción turística de un espacio mítico: peregrinación al cabo de Finisterre. Pasos 7 (2), 163-178.

Kirillova, K., X. Fu, X. Lehto, and L. Cai (2014) What makes a destination beautiful? Dimensions of tourist aesthetic judgment. Tourism Management 42, 282-293.

Kong, L. (2010) Global shifts, theoretical shifts: Changing geographies of religion. Progress in Human Geography 34 (6), 755-776.

Lindkvist, K., and Holmgren, H. (2014) "Famous peripheral Land's End tourists destinations in Europe and their possibilities for creation of Joint Comparative Advantages: proposal for a theoretical approach." In Lois, R., Santos, X., Taboada, P. (eds.) (2014) New tourism in the $21^{\text {st }}$ Century. Cambridge: Cambridge Scholar, 105-125.

Lois, R., and Somoza, J. (2003) Cultural Tourism and Urban Management in NorthWestern Spain: The Pilgrimage to Santiago de Compostela. Tourism Geographies 5 (4), 446-461.

Lois, R., and Santos, X. (2015) Tourists and pilgrims in their way to Santiago. Motives, Caminos and Final destinations. Journal of Tourism and Cultural Change 13 (2), 149164.

MacCannell, D. (1973) Staged authenticity: Arrangements of social space in tourist settings. American Journal of Sociology 793, 589-603.

MacCannell, D. (1976) The tourist: a new theory of the leisure class. New York: Schoken Books.

Mikaelsson, L. (2012) Pilgrimage as postsecular therapy. The Donner Institute for Research in Religious and Cultural History 24, 259-273.

Moberg, M. and Granholm, K. (2012) The concept of the Post-secular and the Contemporary Nexus of Religion, Media, 
Popular Culture and Consumer Culture", in Moberg, M., Granholm, K. and Nynäs, P. (Eds.) Post-Secular Society, New Brunswick, NJ: Transaction Publishers, 95127.

Murray, M., and Graham, B. (1997) Exploring the Dialects of Route-Based Tourism: The Camino de Santiago. Tourism Management 18 (8), 513-524.

Pace, E., and Giordan, G., (2012) Mapping Religion and Spirituality in a Postsecular World, Religion and the Social Order, Leiden:Brill

Poria, Y., Butler, R., and Airey, D. (2003) The Core of Heritage Tourism. Annals of Tourism Research 30 (1), 238-254.

Santos, X. (2002) Pilgrimage and Tourism at Santiago de Compostela. Tourism Recreation Research, 27 (2), 41-50.

Santos, X., and Lois. R. (2011) El Camino de Santiago en el contexto de los nuevos turismos. Estudios Turísticos 189, 95-116.

Sigurdson, O. (2009) Det postsekulära tillståndet. Munkedal: Glänta Produktion.

Shinde, K. (2007) Pilgrimage and the Environment: Challenge in a pilgrimage Centre. Current Issues in Tourism 10 (4), 343-365.

Smith, V. (1992) Introduction: The Quest in Guest. Annals of Tourism Research 19 (1), 1-17.

Taylor, C. (2007) A Secular Age. Cambridge, MA: Belknap Press.
Tilson, D. (2005) Religious-spiritual tourism and promotional campaigning: A church state partnership for St. James and Spain. Journal of Hospitality, Marketing and Management 12 (1), 9-40.

Torpey, J. (2010) A (Post-) Secular Age? Religion and the Two Excepcionalisms. Social Research: An International Quarterly 77 (1), 269-296.

Trillo, B. (1999) As pegadas de Santiago na cultura de Fisterra. Santiago: Municipality of Fisterra-Fundación CaixaGalicia.

Tuan, Y-F., and M. Strawn (2009) Religion From Place to Placelessness. Wisconsin: Center Books on the International Scene.

Turnball, C. (1981) A Pilgrimage in India. Natural History 90 (7), 14-81.

Turner, V. (1969) The Ritual Process. New Jersey: Transaction Publishers.

Turner, V., and Turner, E. (1978) Image and Pilgrimage in Christian Culture. New York: Columbia University Press.

Vukovic, B. (1992) Medjugorje's Religion and Tourism Connection. Annals of Tourism Research 19 (1), 79-91.

Wallenstein, S.-O. (2004) Den moderna arkitekturens filosofier, Stockholm:Alfabeta Bokförlag AB.

Wang, N. (1999) Rethinking Authenticity in Tourism Experience. Annals of Tourism Research 26 (2), 349-370.

Wenngraf, T. (2001) Qualitative Research Interviewing Biographic Narrative and Semi-structed Methods. London: Sage Publications. 